\title{
Synthesis and Structure of Organoaluminum O,C,O Pincer Compounds
}

\author{
Libor Dostäl, ${ }^{\mathrm{a}, *}$ Roman Jambor, ${ }^{\mathrm{a}}$ Ales Růzicka, ${ }^{\mathrm{a}}$ Ivana Císärová, Jaroslav Holecek ${ }^{\mathrm{a}}$ \\ ${ }^{a}$ Department of General and Inorganic Chemistry, Faculty of Chemical Technology, University of \\ Pardubice, Studentská 95, CZ - 532 10, Pardubice, Czech Republic, 'E-mail: \\ libor.dostal@upce.cz: Tel: +42046603 7151; Fax: +420466037068. \\ ${ }^{h}$ Charles University in Prague, Faculty of Natural Science, Hlavova 2030, CZ - 128 40, Prague 2, \\ Czech Republic
}

\begin{abstract}
The set of four organoaluminum compounds containing $\mathrm{O}, \mathrm{C}, \mathrm{O}$ chelating ligands $\left[\begin{array}{lll}2, & 6 & \text { - }\end{array}\right.$ $\left.\left(\mathrm{ROCH}_{2}\right)_{2} \mathrm{C}_{6} \mathrm{H}_{3}\right] \mathrm{AlCl}_{2} ;(\mathrm{R}=\mathrm{Me}(1) ; \mathrm{R}=\mathrm{Et}(2) ; \mathrm{R}=i-\operatorname{Pr}(3) ; \mathrm{R}=t-\mathrm{Bu}(4))$, so called pincer ligands, have been prepared by the metathetical reaction of corresponding organolithium compounds with $\mathrm{AlCl}_{3} \cdot \mathrm{Et}_{3} \mathrm{~N}$ adduct, in moderate yields. Prepared compounds have been characterized by elemental analysis, multinuclear $\left({ }^{1} \mathrm{H},{ }^{13} \mathrm{C}\right.$ and $\left.{ }^{27} \mathrm{Al}\right) \mathrm{NMR}$ spectroscopy and cryoscopy measurements. The monomeric structure of studied compounds $1-4$, containing a five-coordinated central aluminum atom, was obtained in diluted solutions of non-polar solvents (benzene, toluene), while the concentration of the samples resulted in monomer - dimer equilibrium based on ${ }^{1} \mathrm{H},{ }^{27} \mathrm{Al}$ NMR spectroscopy and cryoscopy. The XRD study of 4 revealed a monomeric structure, contanining five-coordinated aluminum located in the centre of a trans-trigonal bipyramid.
\end{abstract}

Keywords: Aluminum, O,C,O chelating ligands, NMR spectroscopy,

\section{INTRODUCTION}

As early as 1955, Bähr and co-workers already reported on the first organoaluminum compounds showing intramolecular interaction $\mathrm{Al}-\mathrm{O}$ in $\left[\mathrm{EtO}\left(\mathrm{CH}_{2}\right)_{4}\right] \mathrm{AlEt}_{2}$ and $\mathrm{Al}-\mathrm{N}$ in $\left[\mathrm{Et}_{2} \mathrm{~N}\left(\mathrm{CH}_{2}\right)_{3}\right] \mathrm{AlEt}_{2}$, respectively $/ 1 \%$ Plenty of intramolecularly stabilized organoaluminum compounds have appeared since that time $/ 2 /$ and some of them contain benzylic bi- or tridentate $\mathbf{N}$ - or $\mathbf{P}$ - donor ligands (Chart 1A) /3/. These intramolecularly stabilized group 13 halides have been often used as precursors for the synthesis of corresponding azides $/ 4$, that constitute valuable candidates for CVD (chemical vapor deposition) of promising materials for microelectronic $\mathrm{AIN}, \mathrm{GaN}$ and $\mathrm{InN} / 5 /$. In contrast to the compounds stabilized by $\mathrm{Al}-\mathrm{N}$, derivatives showing $\mathrm{Al}-\mathrm{O}$ interaction are very rare /1, 2/. Recentlya bidentate benzylic ligand containing an oxygen donor atom $\left(2-\mathrm{CH}_{3} \mathrm{OCH}_{2} \mathrm{C}_{6} \mathrm{H}_{4}\right)$ has also been applied in intramolecular stabilization 
of aluminum (Chart IB). These compounds were used as active cocatalysts for Ziegler-Natta olefin polymerization $/ 6 /$.

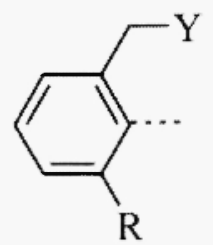

A

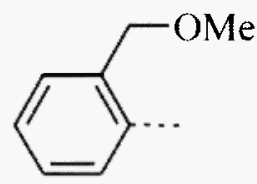

B

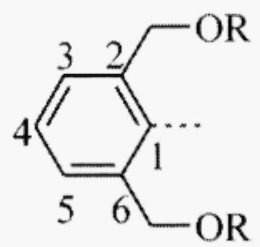

C

$$
\begin{gathered}
\mathrm{Y}=\mathrm{NMe}_{2} ; \mathrm{R}=\mathrm{H} \text { or } \mathrm{CH}_{2} \mathrm{NMe}_{2} \\
\mathrm{Y}-\mathrm{PPh}_{2} ; \mathrm{R}-\mathrm{H}
\end{gathered}
$$

$\mathrm{R}=\mathrm{Me}, \mathrm{Et}, i \mathrm{Pr}, t \mathrm{Bu}$

\section{Chart 1}

We have recently developed a new type of tridentate $\mathrm{O}, \mathrm{C}, \mathrm{O}$ - pincer ligands with increasing steric hindrance $\left(2,6-\left(\mathrm{ROCH}_{2}\right)_{2} \mathrm{C}_{6} \mathrm{H}_{3}\right.$, Chart $\left.1 \mathrm{C}\right)$, that have been used in synthesis of some hypercoordinated organotin(IV) compounds $/ 7 /$ and for stabilization of the corresponding organotin(IV) cations $/ 8 /$. Here we report on synthesis of organoaluminum(III) compounds $\left[2,6-\left(\mathrm{ROCH}_{2}\right)_{2} \mathrm{C}_{6} \mathrm{H}_{3}\right] \mathrm{AlCl}_{2}(\mathbf{1}-\mathbf{4}$, Scheme 1$)$ and on structural studies both in solution (NMR spectroscopy) and in the solid state (XRD of 4). These compounds enable us to observe the dependence of chemical behaviour of $\mathbf{1}-\mathbf{4}$ on increasing ligand steric hindrance as well.

\section{MATERIALS AND METHODS}

\subsection{General comments}

All manipulations were carried out under argon atmosphere using the standard Schlenk technique. All solvents were dried by standard procedures and distilled prior to use. The synthesis of all starting $\mathrm{O}, \mathrm{C}, \mathrm{O}$ ligands (Chart $1 \mathrm{C}$ ) and their lithiation was performed analogously to the literature $/ 7 / .{ }^{1} \mathrm{H},{ }^{13} \mathrm{C}$ and ${ }^{27} \mathrm{Al} \mathrm{NMR}$ spectra were recorded on Bruker AMX360 and Bruker500 Avance spectrometers respectively, using $5 \mathrm{~mm}$ tuneable broad - band probes. Appropriate chemical shifts in ${ }^{1} \mathrm{H}$ and ${ }^{13} \mathrm{C}$ NMR spectra were calibrated on the residual signals of the solvents (benzene- $d_{6}: \delta\left({ }^{1} \mathrm{H}\right)=7.16 \mathrm{ppm}$ and $\delta\left({ }^{13} \mathrm{C}\right)=128.39 \mathrm{ppm}$; toluene- $d_{8}: \delta\left({ }^{1} \mathrm{H}\right)=$ $2.09 \mathrm{ppm}$ and $\left.\delta\left({ }^{13} \mathrm{C}\right)=20.40 \mathrm{ppm}\right) .{ }^{27} \mathrm{Al}$ NMR chemical shifts were related according to the external standard $\left[\mathrm{Al}\left(\mathrm{H}_{2} \mathrm{O}\right)_{6}\right]^{+3} \delta\left({ }^{27} \mathrm{Al}\right)=0.0 \mathrm{ppm}$. Abbreviations used in ${ }^{1} \mathrm{H}$ NMR are: $\mathrm{s}=$ singlet; $\mathrm{d}=$ doublet; $\mathrm{t}=$ triplet; $\mathrm{q}=$ quartet; $\mathrm{h}=$ heptet.

\subsection{Synthesis of $\left[2,6-\left(\mathrm{CH}_{3} \mathrm{OCH}_{2}\right)_{2} \mathrm{C}_{6} \mathrm{H}_{3}\right] \mathrm{AlCl}_{2}(1)$.}

$\mathrm{Et}_{3} \mathrm{~N}(0.95 \mathrm{~g}, 1.30 \mathrm{~mL}, 9.37 \mathrm{mmol})$ was added to the suspension of $\mathrm{AlCl}_{3}(1.25 \mathrm{~g}, 9.37 \mathrm{mmol})$ in toluene $(50 \mathrm{~mL})$. To the resulting solution pre-cooled diethylether solution $\left(-78^{\circ} \mathrm{C}, 30 \mathrm{~mL}\right)$ of $[2,6-$ $\left.\left(\mathrm{CH}_{3} \mathrm{OCH}_{2}\right)_{2} \mathrm{C}_{6} \mathrm{H}_{3}\right] \mathrm{Li}(1.62 \mathrm{~g}, 9.37 \mathrm{mmol})$ was added dropwise. The reaction mixture was stirred for $12 \mathrm{~h}$ at 
room temperature, then insoluble material was filtered off and the filtrate was concentrated to $10 \mathrm{~mL}$. Crystallization at $-30^{\circ} \mathrm{C}$ afforded colourless crystals of 1 . Yield: $1.61 \mathrm{~g}(65 \%)$. M.p.: $82-85^{\circ} \mathrm{C}$. Anal. Calc. for $\mathrm{C}_{10} \mathrm{H}_{13} \mathrm{O}_{2} \mathrm{AlCl}_{2}\left(263.09 \mathrm{~g} \cdot \mathrm{mol}^{-1}\right): \mathrm{C}, 45.65 ; \mathrm{H}, 4.98 ; \mathrm{Cl}, 26.95$. Found: $\mathrm{C}, 45.49 ; \mathrm{H}, 4.82 ; \mathrm{Cl}, 26.88$. Diluted solution - $0.3 \mathrm{M}$ : Molecular weight determination: theor. 263.09 g.mol ${ }^{-1}$; exp. $258.28 \mathrm{~g} \cdot \mathrm{mol}^{-1}$. ' $\mathrm{H}$ $\operatorname{NMR}\left(360 \mathrm{MHz}, \mathrm{C}_{6} \mathrm{D}_{6}, 300 \mathrm{~K}\right): \delta=3.36\left(\mathrm{~s}, 6 \mathrm{H}, \mathrm{OCH}_{3}\right), 4.01\left(\mathrm{~s}, 4 \mathrm{H}, \mathrm{CH}_{2} \mathrm{O}\right), 7.10(\mathrm{~d}, 2 \mathrm{H}, \mathrm{Ar}-H 3,5), 7.23(\mathrm{t}$, $1 \mathrm{H}, \mathrm{Ar}-H 4) .{ }^{13} \mathrm{C}$ NMR $\left(90.6 \mathrm{MHz}, \mathrm{C}_{6} \mathrm{D}_{6}, 300 \mathrm{~K}\right): \delta=58.4\left(2 \mathrm{C}, \mathrm{OCH}_{3}\right), 75.2\left(2 \mathrm{C}, \mathrm{CH}_{2} \mathrm{O}\right), 127.6(2 \mathrm{C}, \mathrm{Ar}-$ $C 3,5), 128.8$ (1C, Ar-C4), 139.3 (2C, Ar-C2,6), Ar- $C$ l not detected. ${ }^{27} \mathrm{Al}$ NMR $\left(93.8 \mathrm{MHz}, \mathrm{C}_{6} \mathrm{D}_{6}, 300 \mathrm{~K}\right): \delta=$ $104, v_{1 / 2}=4.1 \mathrm{kHz}$. High concentration $-1.5 \mathrm{M}$ (NMR signals detected in addition to those obtained in diluted sample): ${ }^{1} \mathrm{H}$ NMR $\left(360 \mathrm{MHz}, \mathrm{C}_{6} \mathrm{D}_{6}, 300 \mathrm{~K}\right): \delta=3.11\left(\mathrm{~s}, 6 \mathrm{H}, \mathrm{OCH}_{3}\right), 4.26\left(\mathrm{~s}, 4 \mathrm{H}, \mathrm{CH}_{2} \mathrm{O}\right), 6.64-7.23$ (complex pattern, $6 \mathrm{H}, \mathrm{Ar}-H) .{ }^{27} \mathrm{Al}-\mathrm{NMR}\left(93.8 \mathrm{MHz}, \mathrm{C}_{6} \mathrm{D}_{6}, 300 \mathrm{~K}\right): \delta=110 \mathrm{ppm}, \mathrm{v}_{1 / 2}=5.3 \mathrm{kHz}$.

\subsection{Synthesis of $\left[2,6-\left(\mathrm{CH}_{3} \mathrm{CH}_{2} \mathrm{OCH}_{2}\right)_{2} \mathrm{C}_{6} \mathrm{H}_{3}\right] \mathrm{AlCl}_{2}$ (2).}

$\mathrm{Et}_{3} \mathrm{~N}(0.72 \mathrm{~g}, 0.99 \mathrm{~mL}, 7.12 \mathrm{mmol})$ was added to the suspension of $\mathrm{AlCl}_{3}(0.95 \mathrm{~g}, 7.12 \mathrm{mmol})$ in toluene $(50 \mathrm{~mL})$. To the resulting solution $\left[2,6-\left(\mathrm{CH}_{3} \mathrm{CH}_{2} \mathrm{OCH}_{2}\right)_{2} \mathrm{C}_{6} \mathrm{H}_{3}\right] \mathrm{Li}(1.42 \mathrm{~g}, 7.12 \mathrm{mmol})$ in hexane $(30 \mathrm{~mL})$ was added dropwise. The reaction mixture was stirred for $12 \mathrm{~h}$ at room temperature, then insoluble material was filtered off and the filtrate was concentrated to $10 \mathrm{~mL}$. Crystallization at $-30^{\circ} \mathrm{C}$ afforded colourless crystals of 2. Yield: $1.24 \mathrm{~g}(60 \%)$. M.p.: $81-83{ }^{\circ} \mathrm{C}$. Anal. Calc. for $\mathrm{C}_{12} \mathrm{H}_{17} \mathrm{O}_{2} \mathrm{AlCl}_{2}\left(291.15 \mathrm{~g} \cdot \mathrm{mol}^{-1}\right)$ : C, $49.50 ; \mathrm{H}$, 5.89; Cl, 24.35. Found: $\mathrm{C}, 49.62 ; \mathrm{H}, 5.91 ; \mathrm{Cl}, 24.47$. Diluted solution - $0.3 \mathrm{M}$ : Molecular weight determination: theor. 291.15 g.mol ${ }^{-1}$; exp. 287.1 g.mol ${ }^{-1}$. ${ }^{1} \mathrm{H}$ NMR $\left(360 \mathrm{MHz}, \mathrm{C}_{6} \mathrm{D}_{6}, 300 \mathrm{~K}\right): \delta=1.06$ (t, $6 \mathrm{H}$, $\left.\mathrm{CH}_{3}\right), 3.34$ (q, 4H, OCH$\left.H_{2}\right), 4.34\left(\mathrm{~s}, 4 \mathrm{H}, \mathrm{CH}_{2} \mathrm{O}\right), 7.18$ (d, 2H, Ar-H3,5), 7.37 (t, 1H, Ar-H4). ${ }^{13} \mathrm{C}$ NMR $(90.6$ $\left.\mathrm{MHz}, \mathrm{C}_{6} \mathrm{D}_{6}, 300 \mathrm{~K}\right): \delta=15.4\left(2 \mathrm{C}, \mathrm{CH}_{3}\right), 65.9\left(2 \mathrm{C}, \mathrm{OCH}_{2}\right), 72.7\left(2 \mathrm{C}, \mathrm{CH}_{2} \mathrm{O}\right), 126.2(2 \mathrm{C}, \mathrm{Ar}-\mathrm{C} 3,5), 128.2(1 \mathrm{C}$, Ar-C4), 139.4 (2C, Ar-C2,6), Ar- $C 1$ not detected. ${ }^{27} \mathrm{Al} \mathrm{NMR}\left(93.8 \mathrm{MHz}, \mathrm{C}_{6} \mathrm{D}_{6}, 300 \mathrm{~K}\right): \delta=102, v_{1 / 2}=3.9$ kHz. High concentration - $1.5 \mathrm{M}$ (NMR signals detected in addition to those obtained in diluted sample): ${ }^{1} \mathrm{H}$ NMR (360 MHz, $\left.\mathrm{C}_{6} \mathrm{D}_{6}, 300 \mathrm{~K}\right): \delta=1.08\left(\mathrm{t}, 6 \mathrm{H}, \mathrm{CH}_{3}\right), 3.90\left(\mathrm{q}, 4 \mathrm{H}, \mathrm{OCH}_{2}\right), 4.19\left(\mathrm{~s}, 4 \mathrm{H}, \mathrm{CH}_{2} \mathrm{O}\right), 6.71-7.37$ (complex pattern, $6 \mathrm{H}, \mathrm{Ar}-H) .{ }^{27} \mathrm{Al}$ NMR $\left(93.8 \mathrm{MHz}, \mathrm{C}_{6} \mathrm{D}_{6}, 300 \mathrm{~K}\right): \delta=108, \mathrm{v}_{1 / 2}=4.8 \mathrm{kHz}$.

\subsection{Synthesis of $\left\{2,6-\left[\left(\mathrm{CH}_{3}\right)_{2} \mathrm{CHOCH}_{2}\right]_{2} \mathrm{C}_{6} \mathrm{H}_{3}\right\} \mathrm{AlCl}_{2}(3)$.}

Procedure as for 2: $\mathrm{AlCl}_{3}(1.1 \mathrm{~g}, 8.25 \mathrm{mmol}),\left\{2,6-\left[\left(\mathrm{CH}_{3}\right)_{2} \mathrm{CHOCH}_{2}\right]_{2} \mathrm{C}_{6} \mathrm{H}_{3}\right\} \mathrm{Li}(1.88 \mathrm{~g}, 8.25 \mathrm{mmol})$. Yield: $1.79 \mathrm{~g}(68 \%)$. M.p. $85-87^{\circ} \mathrm{C}$. Anal. Calc. for $\mathrm{C}_{14} \mathrm{H}_{21} \mathrm{O}_{2} \mathrm{AlCl}_{2}\left(319.20 \mathrm{~g} \cdot \mathrm{mol}^{-1}\right): \mathrm{C}, 52.68 ; \mathrm{H}, 6.63 ; \mathrm{Cl}$, 22.21. Found: $\mathrm{C}, 52.74 ; \mathrm{H}, 6.75 ; \mathrm{Cl}, 22.39$. Diluted solution - $0.3 \mathrm{M}$ : Molecular weight determination: theor. $319.20 \mathrm{~g} \cdot \mathrm{mol}^{-1}$; exp. $312.5 \mathrm{~g} \cdot \mathrm{mol}^{-1}$. ${ }^{1} \mathrm{H}$ NMR $\left(360 \mathrm{MHz}, \mathrm{C}_{6} \mathrm{D}_{6}, 300 \mathrm{~K}\right): \delta=1.10$ (d, $\left.12 \mathrm{H}, \mathrm{CH}_{3}\right), 3.52(\mathrm{~h}, 2 \mathrm{H}$, $\mathrm{OCH}), 4.41\left(\mathrm{~s}, 4 \mathrm{H}, \mathrm{CH}_{2} \mathrm{O}\right), 7.18$ (d, $\left.2 \mathrm{H}, \mathrm{Ar}-\mathrm{H3}, 5\right), 7.45(\mathrm{t}, 1 \mathrm{H}, \mathrm{Ar}-\mathrm{H} 4) .{ }^{13} \mathrm{C} \mathrm{NMR}\left(90.6 \mathrm{MHz}, \mathrm{C}_{6} \mathrm{D}_{6}, 300 \mathrm{~K}\right): \delta$ $=22.6\left(4 \mathrm{C}, \mathrm{CH}_{3}\right), 70.5\left(2 \mathrm{C}, \mathrm{CH}_{2} \mathrm{O}\right), 71.5(2 \mathrm{C}, \mathrm{OCH}), 126.9(2 \mathrm{C}, \mathrm{Ar}-\mathrm{C} 3,5), 128.8(1 \mathrm{C}, \mathrm{Ar}-\mathrm{C} 4), 140.2(2 \mathrm{C}$, Ar- $C 2,6)$, Ar- $C l$ not detected. ${ }^{27} \mathrm{Al}$ NMR $\left(93.8 \mathrm{MHz}, \mathrm{C}_{6} \mathrm{D}_{6}, 300 \mathrm{~K}\right): \delta=103, v_{1 / 2}=4.1 \mathrm{kHz}$. High concentration - 1.5 M (NMR signals detected in addition to those obtained in diluted sample): ${ }^{1} \mathrm{H}$ NMR (360 $\left.\mathrm{MHz}, \mathrm{C}_{6} \mathrm{D}_{6}, 300 \mathrm{~K}\right): \delta=1.19\left(\mathrm{~d}, 12 \mathrm{H}, \mathrm{CH}_{3}\right), 4.33\left(\mathrm{~s}, 4 \mathrm{H}, \mathrm{CH}_{2} \mathrm{O}\right), 4.93(\mathrm{~h}, 2 \mathrm{H}, \mathrm{OCH}), 6.80-7.45$ (complex pattern, $6 \mathrm{H}, \mathrm{Ar}-H) .{ }^{27} \mathrm{Al} \mathrm{NMR}\left(93.8 \mathrm{MHz}, \mathrm{C}_{6} \mathrm{D}_{6}, 300 \mathrm{~K}\right): \delta=109, \mathrm{v}_{1 / 2}=4.9 \mathrm{kHz}$. 


\subsection{Synthesis of $\left\{2,6-\left[\left(\mathrm{CH}_{3}\right)_{3} \mathrm{COCH}_{2}\right]_{2} \mathrm{C}_{6} \mathrm{H}_{3}\right\} \mathrm{AlCl}_{2}(4)$.}

Procedure as for 2: $\mathrm{AlCl}_{3}(0.90 \mathrm{~g}, 6.74 \mathrm{mmol}),\left\{2,6-\left[\left(\mathrm{CH}_{3}\right)_{3} \mathrm{COCH}_{2}\right]_{2} \mathrm{C}_{6} \mathrm{H}_{3}\right\} \mathrm{Li}(1.79 \mathrm{~g}, 6.74 \mathrm{mmol})$. Yield: $1.36 \mathrm{~g}(58 \%)$. M.p.: $88-90^{\circ} \mathrm{C}$. Anal. Calc. for $\mathrm{C}_{16} \mathrm{H}_{25} \mathrm{O}_{2} \mathrm{AlCl}_{2}\left(347.26 \mathrm{~g} \mathrm{~mol}^{-1}\right)$ : C, 55.34; $\mathrm{H}, 7.26 ; \mathrm{Cl}$, 20.42. Found: $\mathrm{C}, 55.48 ; \mathrm{H}, 7.35 ; \mathrm{Cl}, 20.28 \%$. Diluted solution - $0.3 \mathrm{M}$ : Molecular weight determination: theor. 347.26 g.mol ${ }^{-1}$; exp. 350.12 g.mol ${ }^{-1} .{ }^{1} \mathrm{H}-\mathrm{NMR}\left(360 \mathrm{MHz}, \mathrm{C}_{6} \mathrm{D}_{6}, 300 \mathrm{~K}\right): \delta=1.15\left(\mathrm{~s}, 18 \mathrm{H}, \mathrm{CH}_{3}\right), 4.28(\mathrm{~s}$, $\left.4 \mathrm{H}, \mathrm{CH}_{2} \mathrm{O}\right), 7.25$ (d, $\left.2 \mathrm{H}, \mathrm{Ar}-H 3,5\right), 7.50$ (t, $\left.1 \mathrm{H}, \mathrm{Ar}-H 4\right) .{ }^{13} \mathrm{C}$ NMR $\left(90.6 \mathrm{MHz}, \mathrm{C}_{6} \mathrm{D}_{6}, 300 \mathrm{~K}\right): \delta=28.1(6 \mathrm{C}$, $\mathrm{CH}_{3}$ ), 64.6 (2C, $\mathrm{CH}_{2} \mathrm{O}$ ), 73.4 (2C, OC), 126.5 (2C, Ar-C3,5), 128.4 (1C, Ar-C4), 140.9 (2C, Ar-C2,6), Ar-C1 not detected. ${ }^{27} \mathrm{Al}$ NMR (93.8 MHz, $\mathrm{C}_{6} \mathrm{D}_{6}, 300 \mathrm{~K}$ ): $\delta=104, \mathrm{v}_{1 / 2}=3.8 \mathrm{kHz}$. High concentration - 1.5 M (NMR signals detected in addition to those obtained in diluted sample): ${ }^{1} \mathrm{H} \mathrm{NMR}\left(360 \mathrm{MHz}, \mathrm{C}_{6} \mathrm{D}_{6}, 300 \mathrm{~K}\right): \delta=1.45$ (s, $\left.18 \mathrm{H}, \mathrm{CH}_{3}\right), 4.55\left(\mathrm{~s}, 4 \mathrm{H}, \mathrm{CH}_{2} \mathrm{O}\right), 6.80-7.50$ (complex pattern, $\left.6 \mathrm{H}, \mathrm{Ar}-H\right) .{ }^{27} \mathrm{Al} \mathrm{NMR}\left(93.8 \mathrm{MHz}, \mathrm{C}_{6} \mathrm{D}_{6}\right.$, $300 \mathrm{~K}): \delta=110, v_{1 / 2}=5.2 \mathrm{kHz}$.

\subsection{X-ray structure determination}

Colourless crystals of $\mathbf{4}$ suitable for $\mathrm{X}$-ray structure analysis were obtained via crystallisation from diluted toluene solution at $-30{ }^{\circ} \mathrm{C} . \mathrm{C}_{16} \mathrm{H}_{25} \mathrm{O}_{2} \mathrm{AlCl}_{2}, \mathrm{M}=347.24$, orthorhombic, Pbca, $a=11.1050(1) \AA, b=$ 16.1540(2) $\AA, c=20.8340(2) \AA, V=3737.42(7) \AA^{3}, \mathrm{Z}=8, \mathrm{D}_{\mathrm{x}}=1.234 \mathrm{Mg} \mathrm{m}^{-3}$. A colourless air-sensitive crystal of dimensions $0.5 \times 0.45 \times 0.35 \mathrm{~mm}$ was measured on a Nonius KappaCCD diffractometer by monochromatized $\mathrm{MoK} \alpha$ radiation $(\lambda=0.71073 \AA)$ at $150(2) \mathrm{K}$. An absorption was neglected $(\mu=0.396$ $\left.\mathrm{mm}^{-1}\right)$; a total of 55195 diffractions were measured in the range $h=-13$ to $13, k=-19$ to $19, l=-24$ to 24 $\left(\theta_{\max }=25.04^{\circ}\right)$, from which 3291 were unique (Rint $\left.=0.034\right)$ and 2966 observed according to the $l>2 \sigma(l)$ criterion. Cell parameters were calculated from 3702 reflections $\left(\theta=2.43-25.04^{\circ}\right)$. The structure was solved by direct methods (SIR92, Altomare, 1994) and refined by full-matrix least squares based on $F^{2}$ (SHELXL97). The hydrogen atoms were fixed into idealised positions (riding model) and assigned temperature factors, either $\mathrm{H}_{\mathrm{iso}}(\mathrm{H})=1.2 \mathrm{U}_{\mathrm{eq}}$ (pivot atom) or $\mathrm{H}_{\mathrm{iso}}(\mathrm{H})=1.5 \mathrm{U}_{\mathrm{eq}}$ (pivot atom) for methyl moiety. Because of extensive disorder of tert-butyl moieties, their geometry was constrained during refinement. The refinement converged $\left(\Delta / \sigma_{\max }=0.005\right)$ to $R=0.1649$ for observed reflections and $w R=0.5071, G O F=4.960$ for 185 parameters and all 19245 reflections. The quality of diffraction data did not allow to describe disorder satisfactorily, causing the large maxima on the final difference map $\left(\Delta \mathrm{p}_{\max }=1.492, \Delta \rho_{\min }-1.434 \mathrm{e} . \AA^{-3}\right)$ in the vicinity of tert-butyl moieties together with their large displacement parameters.

\section{RESULTS AND DISCUSSION}

\subsection{Synthesis of studied compounds}

The first attempts to prepare compounds 1 - 4 via direct metathesis, using a toluene suspension of $\mathrm{AlCl}_{3}$ and an appropriate organolithium salt (similar procedures have been applied for preparations of analogous compounds containing N,C,N ligands /3d-f/), afforded a mixture of decomposition products only. The similar decomposition of $\mathrm{O}, \mathrm{C}, \mathrm{O}$ ligand has recently been obtained for the reaction of $\left[2,6-\left(\mathrm{ROCH}_{2}\right)_{2} \mathrm{C}_{6} \mathrm{H}_{3}\right] \mathrm{Li}$ with 
$\mathrm{SnCl}_{4} / 7 \%$. This decomposition is most probably the result of a coordination of strong Lewis acids $\left(\mathrm{AlCl}_{3}\right.$ or $\mathrm{SnCl}_{4}$ ) to ethereal oxygen atoms of $\mathrm{O}, \mathrm{C}, \mathrm{O}$ - chelating ligands prior to the desired metathesis reaction, and the propensity of aluminum halides to attack and cleave ethers is well known 19\%. The above discussed conclusion is confirmed by the reaction of unsubstituted ligands $\left[2,6-\left(\mathrm{ROCH}_{2}\right)_{2} \mathrm{C}_{6} \mathrm{H}_{4}\right]$ with $\mathrm{AlCl}_{3}$, that resulted in a similar mixture of decomposition products. This suggestion led to the idea of moderating the reagent $\left(\mathrm{AlCl}_{3}\right)$ propensity to attack ligands by creating its base adduct with $\mathrm{Et}_{3} \mathrm{~N}$. Another advantage of this procedure is the dissolution of $\mathrm{AlCl}_{3}$ in toluene by forming $\mathrm{AlCl}_{3} \mathrm{NEt}_{3}$ adduct. The use of this complex for synthesis of 1 - 4 (Scheme 1), afforded the required compounds in moderate yields (about $60 \%$ ). No trace of $\mathrm{Et}_{3} \mathrm{~N}$ has been detected by ${ }^{1} \mathrm{H}$ NMR spectroscopy in the products after workup. The compounds $\mathbf{1}-\mathbf{4}$ were characterized by elemental analysis, multinuclear NMR spectroscopy, XRD investigation (4) and cryoscopy in benzene.

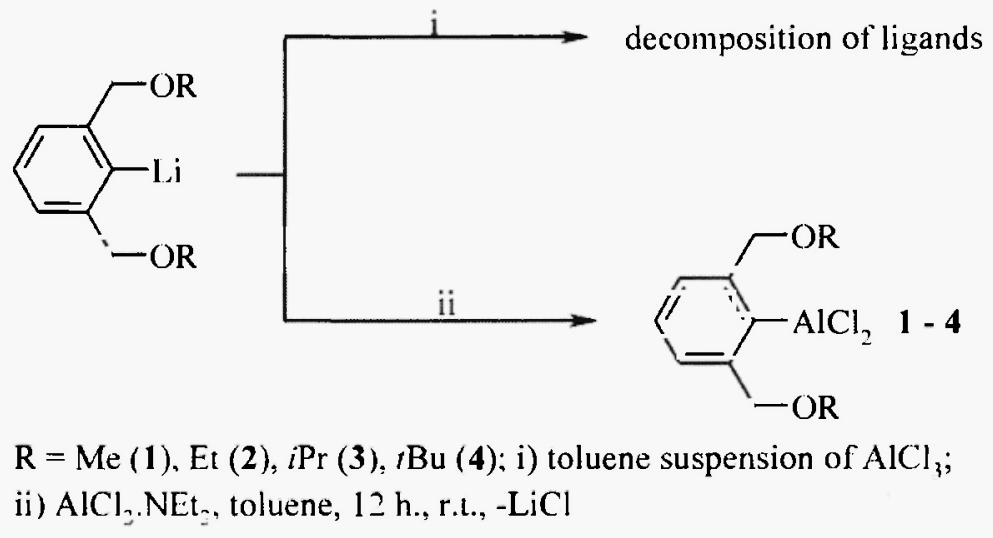

Scheme 1: Synthesis of studied compounds

\subsection{Solution NMR spectroscopy}

${ }^{1} \mathrm{H}$ and ${ }^{13} \mathrm{C}$ NMR spectra of compounds $1-4$ in diluted benzene- $d_{6}$ or toluene- $d_{8}$ solutions (0.3 M) afforded only one set of sharp signals for all protons at $300 \mathrm{~K}$. This resonance pattern in ${ }^{1} \mathrm{H}$ NMR spectra was preserved during the whole studied temperature range $350-180 \mathrm{~K}$ in toluene- $d_{8}$. The ${ }^{27} \mathrm{Al}$ NMR chemical shifts for 1 - 4 fit the region typical for five-coordinated aluminum atoms $/ 10 /$ in organoaluminum compounds (the value of $\delta\left({ }^{27} \mathrm{Al}\right.$ ) [ppm] is 104 for 1,102 for 2,103 for 3,104 for 4), and are similar to those found in the structurally resembling five-coordinated complex $\left\{2,6-\left[\left(\mathrm{CH}_{3} \mathrm{CH}_{2}\right)_{2} \mathrm{NCH}_{2}\right]_{2} \mathrm{C}_{6} \mathrm{H}_{3}\right\} \mathrm{AlCl}_{2} / 3 \mathrm{f} /$. These findings indicate five-coordinated central aluminum atoms (based on the values of $\delta\left({ }^{27} \mathrm{Al}\right)$ ) and the equivalence of both $\mathrm{CH}_{2} \mathrm{OR}$ groups of the ligand (one set of signals in ${ }^{1} \mathrm{H}$ and ${ }^{13} \mathrm{C}$ NMR spectra during the whole studied temperature range). It can be deduced that both oxygen donor atoms of $\mathrm{O}, \mathrm{C}, \mathrm{O}$ - chelating ligands are coordinated to central aluminum atomin mutually trans positions (on the contrary to cis positions of both oxygen atoms in corresponding organotin compounds $/ 7 /$, where $\mathrm{AX}$ spin system has been observed for $\mathrm{CH}_{2} \mathrm{OR}$ groups) through two $\mathrm{Al}$ - $\mathrm{O}$ intramolecular interactions, resulting in trans trigonal bipyramidal geometry in $1-4$. This strong coordination of both oxygen atoms to the central metal (Fig. 2A) is retained in the whole studied temperature range $(350-180 \mathrm{~K})$ - 'H NMR spectrocopy in diluted toluene- $d_{x}$ solutions. 
This conclusion indicates analogous structure of $1-4$, regardless of increasing spatial hindrance of the ligands.

However, more concentrated toluene- $d_{8}$ or benzene- $d_{6}$ solutions $(1.5 \mathrm{M})$ of studied compounds 1 - 4 revealed a second set of signals in addition to the previous one (suggested monomeric structures of $\mathbf{1}-\mathbf{4}$ in $0.3 \mathrm{M}$ solutions) in 'H NMR at $300 \mathrm{~K}$ (Fig. la illustrates the example of the appropriate ${ }^{1} \mathrm{H}$ NMR spectrum of 2). New single resonance was observed in the ${ }^{-7} \mathrm{Al}$ NMR spectra of $\mathbf{1 - 4}$ at this concentration $(1.5 \mathrm{M})$ as well. The values of $\delta\left({ }^{27} \mathrm{Al}\right)$ of new signals varied between $108-111 \mathrm{ppm}$, again proving the five - coordinated central aluminum atoms /10/. The ${ }^{1} \mathrm{H}$ NMR spectra of $\mathbf{1 - 4}$ are concentration dependent, the new resonances observed in concentrated solutions lost their intensities during dilution of the samples and they disappeared at concentration around $0.3 \mathrm{M}$ resulting to 'H NMR spectra consistent with those of monomeric structures of 1 4 (Figs. $\mathrm{lb}$ and $\mathrm{lc}$ illustrates this process on 'H NMR spectra of 2). The whole process is reversible and the concentration of the sample led again to the mixture of two species. The ${ }^{1} \mathrm{H}$ NMR study of $1.5 \mathrm{M}$ toluene- $d_{x}$ solutions of $1-4$ at various temperatures $(350-180 \mathrm{~K})$ revealed the broadening of new $\mathrm{CH}_{2} \mathrm{O}$ group signals (originated from concentration dependent set) below $190 \mathrm{~K}$, while the $\mathrm{CH}_{2} \mathrm{O}$ signals observed both in diluted and concentrated solutions of $1-4$ remained unchanged even at $180 \mathrm{~K}$.

The ratios between both species at $1.5 \mathrm{M}$ concentrations (Fig. la) of $\mathbf{1}-\mathbf{4}$ determined by ${ }^{1} \mathrm{H}$ NMR spectroscopy at $300 \mathrm{~K}$ do not change significantly over the whole studied temperature range $(180-350 \mathrm{~K})$.

These NMR parameters (the values of $\delta\left({ }^{27} \mathrm{Al}\right)$ falling to five coordinated aluminum region and the broadening of new $\mathrm{CH}_{2} \mathrm{O}$ signals below $190 \mathrm{~K}$ indicating a dynamic process in 1 - 4) and well-known inclination of organoaluminum halides to form dimers (even higher adducts) via halide bridges $/ 11$, suggest possible monomer - dimer equilibrium (see Fig. 2). We suppose, that the dimer structures of $1-4$ (bearing central $\mathrm{Al}_{2} \mathrm{Cl}_{2}$ core, and $\mathrm{O}, \mathrm{C}, \mathrm{O}$ chelating ligands with fluxional behaviour) are similar to that found in the solid state for analogous $\mathrm{C}, \mathrm{N}$ - chelated compound (monomeric in solution $/ 3 \mathrm{~b} /$ ) $2-\left[\left(\mathrm{CH}_{3}\right)_{2} \mathrm{NCH}_{2}\right] \mathrm{C}_{6} \mathrm{H}_{4} \mathrm{AlCl}_{2}$ $/ 12 /$. It is interesting, that the other paper reported on the monomeric structure of same compound in solid state $/ 3 \mathrm{~d} /$. The existence of monomer - dimer equilibrium in solution and monomeric structure in the solid state has been observed in intramolecularly stabilized $\left(\mathrm{CH}_{3}\right)_{2} \mathrm{~N}\left(\mathrm{CH}_{2}\right)_{3} \mathrm{Al}\left(\mathrm{CH}_{3}\right)_{2}$ compounds as well /13/. 


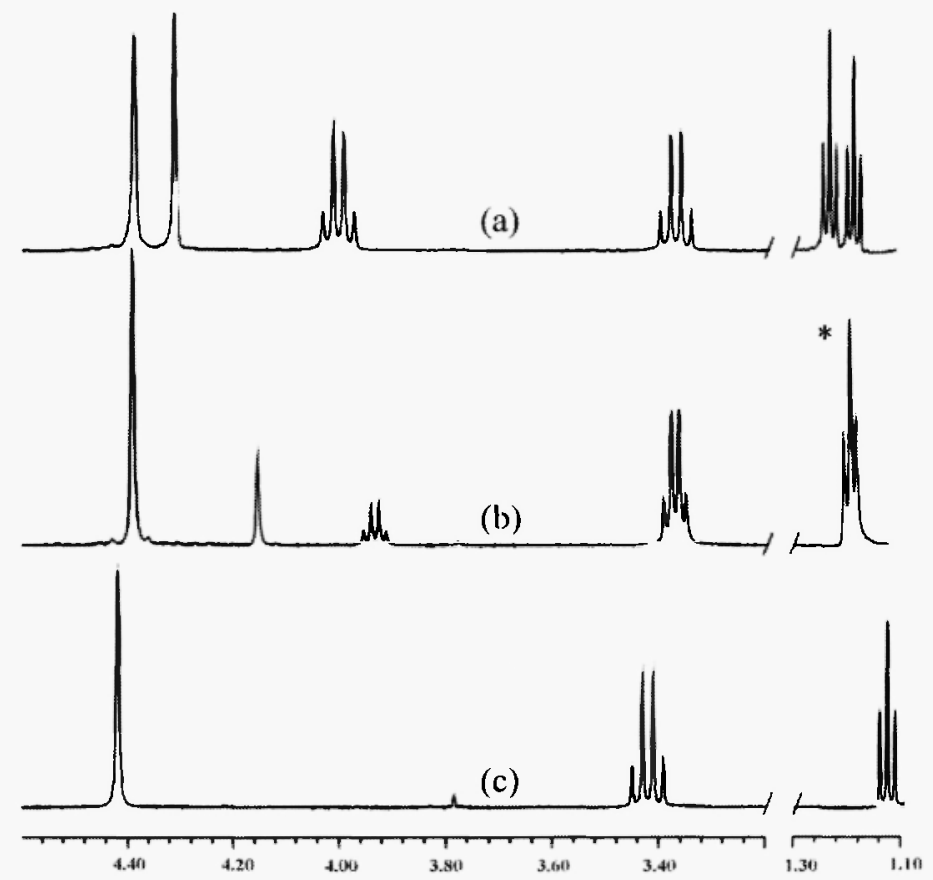

Fig. 1: Aliphatic region of 'H NMR spectra for compound 2 - concentration dependence; $300 \mathrm{~K}$; benzene$d_{6}$ : (a) $1.5 \mathrm{M}$ solution of 2 ; (b) $0.7 \mathrm{M}$ solution of 2 ; (c) $0.3 \mathrm{M}$ solution of 2 ; overlap of two triplets.

These conclusions are in good agreement with results revealed by cryoscopy measurement. The determined molecular weights establish monomeric structure of $1-4$ in $0.3 \mathrm{M}$ benzene solutions (see Experimental section), contrarily to nearly $90 \%$ monomer $-10 \%$ dimer equilibrium detected in more concentrated $(0.5 \mathrm{M})$ benzene solutions, where the molecular weights are $288.24 \mathrm{~g} \cdot \mathrm{mol}^{-1}$ for $1 ; 317.23 \mathrm{~g} \cdot \mathrm{mol}^{-}$ 'for 2; $346.50 \mathrm{~g} \cdot \mathrm{mol}^{-1} 3 ; 378.83 \mathrm{~g} \cdot \mathrm{mol}^{-1} 4$ (theoretical molecular weights of the corresponding monomers are $263.09 \mathrm{~g} \cdot \mathrm{mol}^{-1}$ for $1,291.15 \mathrm{~g} \cdot \mathrm{mol}^{-1}$ for 2, $319.20 \mathrm{~g} \cdot \mathrm{mol}^{-1}$ for 3 and $347.26 \mathrm{~g} \cdot \mathrm{mol}^{-1}$ for 4). These findings coincide with 'H NMR spectroscopy, where the ratios between monomer and dimer (comparison of integral intensities of signals appropriate to $\mathrm{CH}_{2} \mathrm{O}$ groups) are approximately $90 \%$ monomer/10\% dimer in $0.5 \mathrm{M}$ benzene- $d_{6}$ solutions and $67 \% / 33 \%$ in $1.5 \mathrm{M}$ samples.

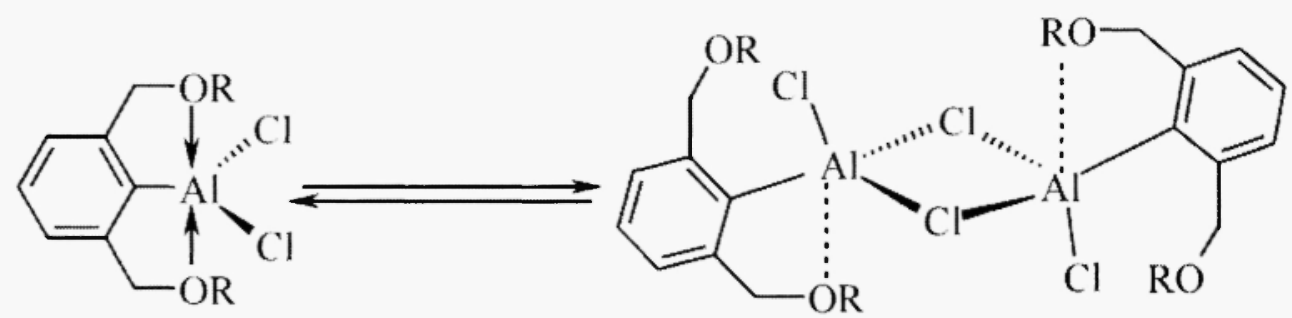

$\Lambda$

B

Fig. 2: Proposed monomer - dimer equilibrium in high concentrated solutions; A monomeric structure, B proposed dimer. 


\subsection{Solid - state structure of 4}

Unfortunately, all single crystals were very mechanically labile, if handled outside the mother liquor, they rapidly decompose to polycrystalline material or thin plates. All other attempts to obtain single crystals by changing experimental conditions (solvent system, temperature, concentration) failed .

In spite of these problems, the solid-state structure of $\mathbf{4}$ was determined by X-ray techniques, however $t$-Bu groups on ligand's skeleton are disordered. The coordination vicinity of aluminum was not influenced by this defect and the main structural parameters can be derived from this structure (Fig. 3).

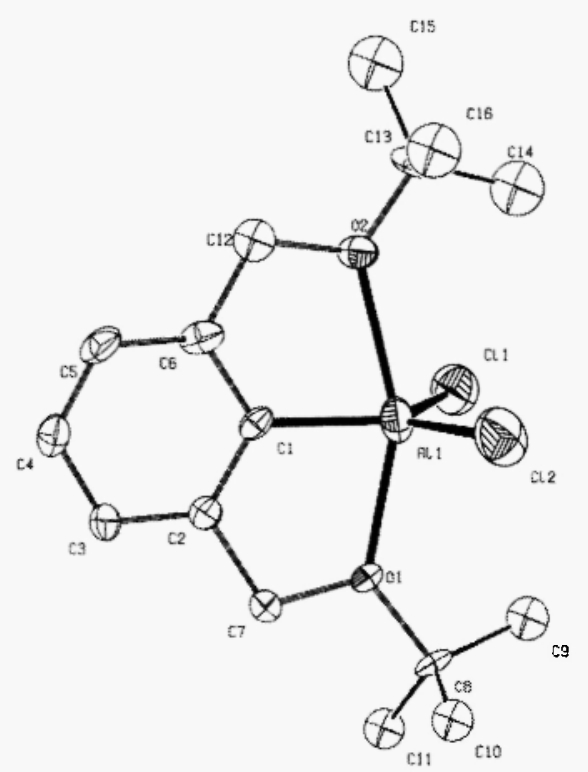

Fig. 3: ORTEP drawing of 4 showing 30\% probability displacement ellipsoids. Hydrogen atoms are omitted for clarity and only one position of disordered $t$-Bu groups is displayed. Selected bond lengths $(\AA)$ and angles $\left({ }^{\circ}\right)$ :All - O1 2.166(5); All - O2 2.338(4); O1 - All - O2 156.31(17).

The five-coordinated aluminum atom is located in the center of a distorted trans - trigonal bipyramid, where both oxygen donor atoms $\mathrm{O}(1)$ and $\mathrm{O}(2)$ adopt pseudo axial positions (while in corresponding organotin compounds both oxygeil atoms were bound in mutually cis positions /7/), and both chlorines $\mathrm{Cl}(1)$ and $\mathrm{Cl}(2)$ together with carbon $\mathrm{C}(1)$ form the equatorial plane. The sum of angles in the $\mathrm{Cl}(1)-\mathrm{Cl}(2)-\mathrm{C}(1)$ girdle almost accurately attains the ideal value for equatorial plane by $359.87^{\circ}(17)$. The notable deviation from ideal environment is the magnitude of angle $\mathrm{O}(1)-\mathrm{Al}(1)-\mathrm{O}(2) 156.31(17)^{\circ}$, but this defect is constrained by rigidity of the pincer ligand. The same type of deviation from ideal trigonal bipyramidal shape was observed for structurally similar compound $\left\{2,6-\left[\left(\mathrm{CH}_{3} \mathrm{CH}_{2}\right)_{2} \mathrm{NCH}_{2}\right]_{2} \mathrm{C}_{6} \mathrm{H}_{3}\right\} \mathrm{AlCl}_{2}$, where the angle $\mathrm{N}-\mathrm{Al}$ - $\mathrm{N}\left(158.19(10)^{\circ}\right)$ was determined $/ 3 \mathrm{f} /$. One of the $\mathrm{Al}-\mathrm{O}$ distances $\mathrm{Al}(1)-\mathrm{O}(1) 2.166(5) \AA$ is considerably shorter than the second one $\mathrm{Al}(1)-\mathrm{O}(2) 2.338(4) \AA$, but both approximate the covalent bond distance for $\mathrm{Al}$ $\mathrm{O}$ bond $1.92 \AA / 14 \mathrm{a} /$ and are considerably shorter than the sum of van der Waals radii of $\mathrm{Al}$ and $\mathrm{O} 3.52 \AA$ $/ 14 \mathrm{~b} /$, thus confirming the existence of a strong intramolecular interaction between both oxygen donor atoms and the central aluminum atom. The $\mathrm{Al}(1)-\mathrm{O}(1)$ bond distance is comparable to those found in other intramolecularly coordinated compounds $\left[2-\mathrm{CH}_{3} \mathrm{OC}_{6} \mathrm{H}_{4} \mathrm{CH}_{2}\right]_{2} \mathrm{AlCH}_{3} 2.1523(17) ;\left[2-\mathrm{CH}_{3} \mathrm{OC}_{6} \mathrm{H}_{4} \mathrm{CH}_{2}\right]_{2} \mathrm{AlCl}$ 
$2.0700(11) ;\left[8-\mathrm{CH}_{3} \mathrm{OC}_{10} \mathrm{H}_{6}\right]_{2} \mathrm{AlCH}_{3} 2.135(3)$ and $\left[8-\mathrm{CH}_{3} \mathrm{CH}_{2} \mathrm{OC}_{10} \mathrm{H}_{6}\right]_{2} \mathrm{AlCl} 2.120(4) / 6 /$.

\section{CONCLUSIONS}

Metathetical reaction using $\mathrm{AlCl}_{3} \cdot \mathrm{Et}_{3} \mathrm{~N}$ has been applied for preparation of the studied compounds. Analogous behaviour has been observed for studied compounds 1 - 4 in solution, in spite of increasing steric hindrance of the O,C,O pincer ligand. Monomeric structures of 1 - 4 (similar to that detected for 4 in the solid state) have been confirmed in diluted solutions mainly by multinuclear spectroscopy and cryoscopy in benzene. However, a concentration-dependent equilibrium (monomer/dimer) has been established in high concentrated solutions for $\mathbf{1}-\mathbf{4}$.

\section{SUPPORTING INFORMATION}

Crystallographic data for structural analysis have been deposited with the Cambridge Crystallographic Data Centre, CCDC no. 232261. Copies of this information may be obtained free of charge from The Director, CCDC, 12 Union Road, Cambridge CB2 1EY, UK (Fax: +44-1223-336033; e-mail: deposit(a)ccdc.cam.ac.uk or www: http://www.ccdc.cam.ac.uk).

\section{ACKNOWLEDGEMENTS}

The authors wish to thank the Grant Agency of the Czech Republic (grant No. 203/03/P128) and the Ministry of Education of the Czech Republic (project No. LN00A028; project FRVŠ 330211 - L.D. and J.H.) for financial support.

\section{REFERENCES}

1. G. Bähr, G. E. Müller, Chem. Ber. 88 (1955) 251.

2. G. J. M. Gruter, G. P. M. van Klink, O. S. Akkerman, F. Bickelhaupt, Chem. Rev. 95 (1995) 2405 and references cited therein.

3. (a) J. Müller, R. Schröder, R. Wang, Eur. J. Inorg. Chem. 2000, 153. (b) J. Müller, U. Englert. Chem. Ber. 128 (1995) 493. (c) G. Müller, J. Lachmann, A. Rufinska, Organometallics 11 (1992) 2970. (d) Ch. Böker, M. Noltemeyer, H. Gornitzka, B. O. Kneisel, M. Teichert, R. H. Irmer, A. Meller, Main Group Met. Chem. 21 (1998) 565. (e) L. Contreras, A. H. Cowley, F. P. Gabbai, R. A. Jones, C. J. Carrano, M. R. Bond, J. Organomet. Chem. 489 (1995) Cl. (f) M. Stender, U. Segerer, J. Sieler, E. H. Hawkins, Z. Anorg. Allg. Chem. 624 (1995) 85. 
4. (a) R. A. Fischer, A. Miehr, H. Sussek, H. Pritzkow, E. Herdtweck, J. Müller, O. Ambacher, T. Metzger, J. Chem. Soc. Chem. Commun. 1996, 2685. (b) J. Müller, R. A. Fischer, H. Sussek, P. Pilgram, R. Wang, H. Pritzkow, E. Herdtweck, Organometallics 17 (1998) 161. (c) A. Miehr, M. R. Mattner, R. A. Fischer, Organometallics 15 (1996) 2053.

5. (a) D. A. Neumayer, J.G. Ekerdt, Chem. Mater. 8 (1996) 9. (b) A. C. Jones, P. O'Brien, CVD of Compound Semiconductors, VCH, Weinheim, 1997. (c) R. A. Fischer, A. Miehr, E. Herdtweck, M. R. Mattner, O. Ambacher, T. Metzger, E. Born, S. Weinkauf, C. R. Pulham, S. Parsons, Chem. Eur. J. 2 (1996) 1353.

6. H. Schumann, S. Dechert, S. Schutte, J. Y. Hyeon, M. Hummert, B. C.Wassermann, W. Kaminsky, A. Eisenhardt, K. Köhler, J. Eichhorn, Organometallics 22 (2003) 1391.

7. R. Jambor, L. Dostál, A. Růzička, l. Císarová, J. Brus, J. Holeček, Organometallics 19 (2002) 3996.

8. B. Kasná, R. Jambor, L. Dostál, A. Ruzicka, I. Cisarová, J. Holeček, Organometallics in press.

9. J. J. Eisch, Comprehensive Organometallic Chemistry vol. 1 (1982) 652.

10. (a) R. Benn, A. Rufinska, H, Lehmkuhl, E. Janssen, C. Krüger, Angew. Chem. 95 (1983) 808; R. Benn, A. Rufinska, H, Lehmkuhl, E. Janssen, C. Krüger, Angew. Chem. Ind. Ed. 22 (1983) 779. (b) R. Benn, E. Janssen, H. Lehmkuhl, A. Rufïnska, J. Organomet. Chem. 333 (1987)155. (c) J. W. Akitt, Prog. NMR Spectrosc. 21 (1989) 1.

11. (a) M. S. Lalama, J. Kampf, D. G. Dick, J. P. Oliver, Organometallics 14 (1995) 495. (b) R. J. Wehmschulte, W. J. Grigsby, B. Schiemenz, R. A. Barlett, P. P. Power, Inorg. Chem. 35 (1996) 6694. (c) C. N. McMahon, J. A. Francis, A. R. Barron, J. Chem. Cryst. 27 (1997) 191. (d) P. R. Schonberg, R. T. Paine, C. F. Campana, E. N. Duesler, Organometallics 1 (1982) 799. (e) P. R. Schonberg, R. T. Paine, C. F. Campana, J. Am. Chem. Soc. 101 (1979) 7726. (f) M. Schurmann, K. S. Klimek, H. Hatop, S. P. Varkey, H. W. Roesky, C. Lehman, C. Ropken, R. Herbst - Irmer, M. Noltemeyer, J. Solid State Chem. 162 (2001) 225.

12. M. A. Dam, O. S. Akkerman, F. Bickelhaupt, N. Veldman, A. L. Spek, Main Group Met. Chem. 18 (1995) 633.

13. H. Schumann, B. C. Wassermann, S. Schutte, B. Heymer, S. Nickel, T. D. Seuß, S. Wenrik, J. Demtschuk, F. Girgdies, R. Weinmann, Z. Anorg. Allg. Chem. 626 (2000) 2081.

14. (a) L. Pauling, The Nature of the Chemical Bond and The Structure of Molecules and Crystals, Oxford University Press (1948). (b) A. Bondi, J. Phys. Chem. 68 (1964) 441. 